\title{
Pengaruh Pengelolaan Pembelajaran Terhadap Prestasi Belajar Mahasiswa Semester III Program Studi Pendidikan Biologi STKIP Bima Tahun 2017/2018
}

\author{
Anita Rahmawati \\ Program Studi Pendidikan Biologi, STKIP Bima. Jalan Piere Tendean Kel. Mande Tel. Fax (0374) \\ 42801, Bima 84191, Indonesia. \\ Email: anitarahmawati909@gmail.com
}

\begin{abstract}
Abstrak
Penelitian ini bertujuan untuk: Mengetahui seberapa besar pengaruh pengelolaan pembelajaran terhadap prestasi belajar mahasiswa kelas B semester III Jurusan Biologi STKIP Bima tahun ajaran 2017/2018. Jenis penelitian ini adalah penelitian kuantitatif dengan menggunakan populasi dan sampel yaitu seluruh mahasiswa kelas B Semester III Jurusan Biologi STKIP Bima yang berjumlah 41 orang. Teknik pengumpulan data berupa angket, wawancara, dan dokumentasi. Dan di analisis menggunakan teknik regresi linier sederhana, uji t, uji F, dan uji determinasi. Hasil penelitian menunjukkan (1) Pengelolaan pembelajaran berpengaruh signifikan terhadap prestasi belajar mahasiswa kelas B semester III Jurusan Biologi STKIP Bima tahun ajaran 2017/2018 yang ditunjukkan dengan uji hipotesis yang diperoleh nilai signifikansi $0,000<0,05$ dan $t_{\text {hitung }}>t_{\text {tabel }}$ yaitu 4,594 $>2,045$ sedangkan perolehan dari uji keberartian linier adalah $(0,000<0,05)$ dan $\mathrm{f}_{\text {hitung }}>\mathrm{f}_{\text {tabel }}$ dengan $\mathrm{DF}(1,30) \alpha=5 \%$, maka $(21,102$ $>4,17$ ), (2) Dari hasil uji determinasi sebesar 0,413 menunjukkan bahwa pengelolaan pembelajaran berpengaruh cukup terhadap prestasi belajar di STKIP Bima tahun ajaran 2017/2018 yang ditunjukan dengan hasil uji determinasi (R2) sebesar 0,413 artinya bahwa besarnya pengaruh pengelolaan pembelajaran terhadap prestasi belajar adalah sebesar $41,3 \%$, sedangkan 58,7\% sisanya dipengaruhi oleh variabel lain yang tidak diteliti.
\end{abstract}

Kata Kunci: Pengaruh Pengelolaan Pembelajaran, Prestasi Belajar.

\section{PENDAHULUAN}

Pengelolaan berasal dari kata "kelola" atau "manajemen" yang artinya ketatalaksanaan, tata pimpinan. Maka disimpulkan pengelolaan itu adalah pengadministrasian, pengaturan atau penataan suatu kegiatan atau proses yang memberikan pengawasan pada semua hal yang terlibat dalam pelaksanaan kebijaksanaan dan pencapaian tujuan.

Sedangkan pembelajaran berasal dari kata "belajar" yang artinya suatu kegiatan yang dilakukan untuk mencari informasi. Menurut Sudjana (2009), pengelolaan pembelajaran merupakan kegiatan memproyeksikan tindakan apa yang akan dilaksanakan dalam suatu pembelajaran yaitu dengan mengkoordinasikan (mengatur dan merespon) komponenkomponen pembelajaran sehingga antara tujuan, materi, metode serta evaluasi menjadi jelas dan sistematis.

Dalam pelaksanaan pembelajaran diharapkan mampu memahami tentang bagaimana cara mengelola pembelajaran dengan baik. Pengelolaan pembelajaran merupakan sesuatu yang penting dalam pendidikan karena tanpa adanya pengelolaan pembelajaran maka proses pembelajaran tidak 
akan terarah dengan baik sehingga tujuan pembelajaran yang telah ditetapkan tidak akan tercapai secara optimal.

Pengelolaan pembelajaran tidak hanya berupa pengaturan kelas, fasilitas fisik dan rutinitas. Kegiatan pengelolaan pembelajaran dimaksudkan untuk menciptakan dan mempertahankan suasana dan kondisi belajar. Sehingga proses belajar mengajar dapat berlangsung secara efektif dan efisien.

Rumusan masalah dalam penelitian ini adalah (1) Bagaimana Pengelolaan Pembelajaran di STKIP Bima?. (2) Bagaimana Prestasi Belajar Mahasiswa di STKIP Bima?. (3) Bagaimana Pengaruh Pengelolaan Pembelajaran terhadap Prestasi Belajar Mahasiswa di STKIP Bima. Dengan tujuan untuk mengetahui pengaruh pengelolaan pembelajaran terhadap prestasi belajar mahasiswa di STKIP Bima.

\section{METODE}

Metode penelitian yang digunakan adalah penelitian deskritif kuantitatif, dimana penelitian ini mendeskripsikan hubungan antara variabel-variabel bebas yakni pengelolaan pembelajaran terhadap variabel terikat yakni prestasi belajar mahasiswa. Penelitian ini dilakasanakan di Sekolah Tinggi Keguruan dan Ilmu Pendidikan (STKIP) Bima dengan populasi mahasiswa kelas B semester III, dan untuk sampelnya berjumlah 41 mahasiswa dari keseluruhan populasi. Teknik sampling yang digunakan adalah teknik stratified populasi sampling yaitu semua yang menjadi populasi menjadi sampel (Arikunto, (2010: 173).

Variabel dalam penelitian ini terdiri dari variabel bebas (independen) dan variabel terikat (dependen). Variabel bebas adalah variabel yang merupakan rangsangan untuk mempengaruhi variabel lain. Sedangkan variabel terikat adalah suatu jawaban atas hasil perilaku yang dirangsang (Rubiyanto. (2013: 23). Variabel bebas dalam penelitian ini adalah pengelolaan pembelajaran (X) sedangkan variabel terikat dalam penelitian ini adalah prestasi belajar mahasiswa (Y).

Dalam penelitian ini menggunakan instrumen berupa item-item pernyataan dalam bentuk angket jumlah reponden 41 mahasiswa.

Hasil uji coba instrumen dianalisis dengan menggunakan uji validitas dan uji reliabilitas. Hasil dari pengumpulan data kemudian diuji dengan menggunakan uji prasyarat analisis yang terdiri dari uji normalitas dan uji linieritas. Sedangkan teknik analisis data menggunakan analisis regresi linear sederhana kemudian dilakukan pengujian hipotesis. Pengujian hipotesis yang dilakukan adalah dengan pengujian hipotesis (uji t), kemudian dilanjutkan dengan pengujian keberartian regresi (uji F) yang berupa pengaruh variabel $\mathrm{X}$ (pengelolana pembelajaran) terhadap variabel $\mathrm{Y}$ (prestasi 
belajar mahasiswa). Kemudian dilanjutkan dengan penghitungan koefisien determinasi untuk mengetahui seberapa besar prosentase pengaruh variabel $\mathrm{X}$ (pengelolaan pembelajaran) terhadap variabel Y (prestasi belajar).

\section{HASIL DAN PEMBAHASAN}

Berdasarkan hasil uji validitas yang menggunakan rumus korelasi product moment diperoleh variabel pengelolaan pembelajaran diketahui mempunyai 5 item pernyataan yang dinyatakan tidak valid yaitu nomer 2,5,7,11, dan 19, untuk variabel prestasi belajar 4 item dinyatakan tidak valid yaitu nomer 4,6,13 dan 15. Item-item yang valid digunakan sebagai instrumen pengumpulan data, sedangkan item yang tidak valid dihilangkan sebagai instrumen pengumpulan data. Berdasarkan hasil uji reliabilitas diperoleh nilai koefisien reliabilitas angket pengelolaan pembelajaran sebesar 0,773, dan angket prestasi belajar mahasiswa sebesar 0,738. Berdasarkan nilai koefisien reliabilitas tersebut dapat dinyatakan bahwa angket pengelolaan pembelajaran dan prestasi belajar mahasiswa memiliki reliabilitas yang tinggi berdasarkan uji validitas dan reliabilitas maka angket pengelolaan pembelajaran dan prestasi belajar mahasiswa sudah layak digunakan sebagai istrumen penelitian, karena item pertanyaan yang digunakan adalah valid dan reliabel.
Hasil uji prasyarat analisis diperoleh melalui uji normalitas dan linearitas. Uji normalitas dilakukan untuk mengetahui normal tidaknya suatu distribusi data. Teknik uji yang digunakan adalah uji Liliefors pada taraf signifikansi 0,05. Adapun rangkuman hasil uji normalitas yakni Nilai signifikansi variabel pengelolaan pembelajaran dan prestasi belajar adalah 0,200 , berdasarkan nilai tersebut maka nilai signifikansi variabel pengelolaan pembelajaran dan prestasi belajar mahasiswa lebih besar dari 0,05 $(0,200>0,05)$ maka data dapat dikatakan berdistribusi normal.

Uji linearitas digunakan untuk mengetahui apakah dua variabel mempunyai hubungan yang linear atau tidak secara signifikan. Penghitungan pengujian ini dengan menggunakan bantuan program SPSS 20.0. Berdasarkan perhitungan uji linieritas diperoleh harga $F$ sebesar 1,801, F sebesar 2,37dan nilai signifikan > 0,05 $(0,129>0,05)$ hasilnya adalah $F_{\text {hitung }}<F_{\text {tabel }}(1,801<2,37)$ sehingga dapat disimpulkan bahwa hubungan antara pengelolaan pembelajaran dan prestasi belajar mahasiswa merupakan hubungan linier.

Dilakukan analisis regresi linear sederhana dengan bantuan SPSS ver. 20.0. Hasil penelitian menunjukkan bahwa pengelolaan pembelajaran mempunyai pengaruh terhadap prestasi belajar. Hal ini dapat dilihat dari persamaan regresi linear sederhana yaitu $\mathrm{Y}=11,462+0,650 \mathrm{X}$., 
berdasarkan persamaan tersebut terlihat bahwa koefisien regresi dari variabel indepeden bernilai positif, artinya pengelolaan pembelajaran berpengaruh positif terhadap minat belajar. Nilai 11,462, menyatakan bahwa jika pengelolaan pembelajaran tetap (tidak mengalami perubahan) maka pengelolaan pembelajaran sebesar 11,462, untuk nilai 0,650 menyatakan bahwa jika pengelolaan pembelajaran bertambah sebesar 1 poin maka prestasi belajar mahasiswa akan mengalami peningkatan sebesar 0,650 (dengan asumsi tidak ada penambahan (konstan) nilai pengelolaan pembelajaran).

Selanjutnya setelah dilakukan analisis regresi sederhana maka langkah selanjutnya adalah menguji hipotesis untuk mengetahui seberapa besar pengaruh pengelolaan pembelajaran terhadap prestasi belajar mahasiswa, maka digunakan uji t dan uji $F$ yang meliputi: uji hipotesis diperoleh $t_{\text {hitung }}>t_{\text {tabel }}$ yaitu 4,594 > 2,045, dan nilai signifikansi < 0,05, yaitu 0,000 dan diketahui Ada pengaruh yang signifikan antara pengelolaan pembelajaran terhadap prestasi belajar mahasiswa Kemudian berdasarkan uji keberartian linear sederhana variabel pengelolaan pembelajaran terhadap prestasi belajar mahasiswa Fhitung > Ftabel yaitu $21.102>4,17$, dan nilai signifikansi < 0,05, yaitu 0,000 sehingga dapat disimpulkan bahwa ada pengaruh yang signifikan antara pengelolaan pembelajaran terhadap prestasi belajar mahasiswa. Sedangkan berdasarkan perhitungan analisi data koefisien determinasi diperoleh nilai koefisien determinasi (R2) sebesar 0,413 yang berarti bahwa pengaruh yang diberikan oleh variabel pengelolaan pembelajaran terhadap prestasi belajar mahasiswa adalah $41,3 \%$, sedangkan sisanya sebesar 58,7\% dipengaruhi oleh variabel lain.

\section{KESIMPULAN}

Berdasarkan hasil penelitian yang dilakukan pada mahasiswa kelas B semester III jurusan biologi di STKIP Bima, dapat di tarik kesimpulan sebagai berikut: (1) Pengelolaan pembelajaran berpengaruh signifikan terhadap prestasi belajar mahasiswa kelas B semester III jurusan biologi STKIP Bima tahun ajaran 2017/2018. (2) Pengelolaan pembelajaran berpengaruh terhadap prestasi belajar mahasiswa kelas B semester III jurusan biologi STKIP Bima tahun ajaran 2017/2018, dengan persamaan regresi $\mathrm{Y}=11,462+0,650 \mathrm{X}$, dimana nilai signifikansi kurang dari 0,05 $(0,000<0,05)$ dan $f_{\text {hitung }}>f_{\text {tabel }}$ dengan DF $(1$, 30) $\alpha=5 \%$, maka $(21,102>4,17)$. Dengan demikian hipotesis yang berbunyi "adakah pengaruh pengelolaan pembelajaran terhadap prestasi belajar mahasiswa kelas B semester III Jurusan Biologi STKIP Bima" diterima. (3) Hasil uji determinasi (R2) sebesar 0,413 menunjukkan bahwa besarnya pengaruh pengelolaan pembelajaran terhadap prestasi 
belajar mahasiswa kelas B semester III Jurusan

Biologi STKIP Bima tahun ajaran 2017/2018, adalah sebesar $41,3 \%$, sedangkan sisanya 58,7 $\%$ sisanya dipengaruhi oleh variabel lain yang tidak diteliti.

\section{DAFTAR PUSTAKA}

Arikunto, Suharsimi. 2010. Prosedur Penelitian. Jakarta: Rineka Cipta.

Sudjana, Nana. 2009. Dasar-Dasar Proses Belajar Mengajar. Bandung: Sinar Baru Algesindo.

Rohani, Ahmad. 2010. Pengelolaan Pengajaran. Jakarta: Rineka Cipta.

Slameto. 2013. Belajar dan Faktor-Faktor yang Mempengaruhinya. Jakarta: Rineka Cipta.

Suprijanto. 2008, Pendidikan Orang Dewasa dari Teori Hingga Aplikasi, Jakarta : Bumi Aksara.

Rubiyanto, Rubino. 2013. Penelitian Pendidikan. Surakarta: Universitas Muhammadiyah Surakarta.

Tirta, Nyoman. 1979. Perkembangan Personalitas dan Teori Belajar. Singaraja : Biro Penelitian dan Penerbitan FKIP UNUD. 